\title{
Determination of Specific and Non-Specific Parameters of Simplicia and Ethanolic 70\% Extract of Gadung Tubers (Dioscorea hispida)
}

\author{
Sasmita Retno Sari, Berna Elya*, Katrin
}

\section{Sasmita Retno Sari, Berna Elya*, Katrin}

Department of Pharmacognosy and Phytochemistry, Faculty of Pharmacy, Universitas Indonesia, Depok 16424 West Java, INDONESIA.

\section{Correspondence}

\section{Berna Elya}

Department of Pharmacognosy and Phytochemistry, Faculty of Pharmacy, Universitas Indonesia, Depok 16424 West Java, INDONESIA.

Phone no: +6281314161497

E-mail: berna.elya@farmasi.ui.ac.id

History

- Submission Date: 20-01-2019;

- Review completed: 03-04-2019;

- Accepted Date: 01-05-2019.

\section{DOI : 10.5530/pj.2019.11.120}

Article Available online

http://www.phcogj.com/v11/i4

\section{Copyright}

(C) 2019 Phcogj.Com. This is an open access article distributed under the terms of the Creative Commons Attribution 4.0 International license.

\begin{abstract}
Background: D. hispida can be used as a painkiller, rheumatic drugs and antioxidant. Based on its medicinal properties, D. hispida can be used as a traditional medicine that must be guaranteed on quality, safety and benefit. Therefore, standardization is needed. This aim of this study was to obtain some specific and non-specific parameter of simplicia and ethanolic $70 \%$ extract of $D$. hispida tubers from three different regions. Materials and Methods: The samples were macerated by using ethanol $70 \%$. Results: The results showed that the specific parameters of D. hispida simplicia; the total water soluble extract was $11.25-16.20 \%$; the total ethanol soluble extract was 6.42-9.39\%; the chromatogram profile was obtained by using thin layer chromatography in toluene-ethyl acetate-chloroform (5:1:4) mobile phase with $\beta$-sitosterol as standard, the total phenolic content was $2.15-2.50$ expressed in $\mathrm{mgGAE} / \mathrm{g}$ simplicia. The non-specific parameters of $D$. hispida simplicia; the total loss on drying was 10.53-12.40\%; the total ash content was 5.81-5.94\%; the total acid insoluble ash content was $0.20-0.22 \%$. The specific parameters of $D$. hispida extract; the total phenolic content was 10.30-11.72 expressed in mgGAE/g extract. The non-specific parameters of $D$. hispida extract; the total water content was $10.27-10.47 \%$; the total ash content was $2.84-2.93 \%$; the total acid insoluble ash content was 0.14-0.19. Conclusion: conform the parameters.
\end{abstract}

Key words: D. hispida, Gadung, Non-specific parameter, Specific parameter, Standardization.

\section{INTRODUCTION}

D. hispida is an herb plant belongs to the Dioscoreaceae family, grows and develops in the tropics. ${ }^{1}$ D. hispida contains saponins, alkaloids namely dioscorin, flavonoid, tannins, carbohydrates, proteins, glycosides, phenols and phytosterols. ${ }^{2-4}$ Some species of the genus Dioscorea contains steroid saponin, namely diosgenin as a precursor to synthesize steroid drugs. ${ }^{5}$ D. hispida tubers can be used as a painkiller and rheumatic drugs. ${ }^{2}$ Based on the research of $\mathrm{Lu}$, Chia, Liu and Hou (2012) and Panduranga et al, (2011), D. hispida tubers have pharmacological activities such as antioxidants, antihypertensive, immunomodulators, anthelmintics, antiinflammatory, antitumor and analgesics. ${ }^{6,7}$

Maceration is a method of extracting simplicia at room temperature by using a solvent with several times of shaking. In the maceration method, the principle used is achieving concentration on balance. Kinetic maceration is maceration with continuous stirring. Meanwhile, remaceration is maceration by adding solvent repeatedly after the screening of the first mass. ${ }^{8}$

Standardization is a set of parameters, procedures and methods of measurement whose results are elements related to the paradigm of pharmaceutical quality, quality means to conform the standard requirements (chemistry, biology and pharmacy), including the guarantee (limits) of stability as a general pharmaceutical product. Standardization also means to guarantee that the final product (medicine, extract or extract product) has a constant parameter value (steady) and determined (designed in a formula) first. ${ }^{8}$

Simplicia standardization means that simplicia will be used for medicine as a raw material must conform to the requirements in the Ministry of Health monograph (Materia Medika Indonesia). Extracts that are used as raw materials or pharmaceutical products must conform in the monograph of raw materials (simplicia) and standard parameters extract requirements. The requirements for simplicia and extract quality consist of specific parameters and general (non-specific) parameters. ${ }^{8}$

\section{MATERIALS AND METHODS}

\section{Materials}

Tubers of D. hispida was obtained from the Center for Plant Conservation-Bogor Botanical Garden. All other chemical and reagent were source commercially. $\beta$-sitosterol from Sigma Aldrich (Singapore), gallic acid from Sigma Aldrich (Singapore), ethanol from Merck (Germany), n-hexane from Merck (Germany), ethyl acetate from Merck (Germany), methanol from Merck (Germany), toluene from Merck (Germany), chloroform from Merck (Germany).

\section{Preparation of extracts}

D. hispida was collected from Bogor, Sragen and Gunung Kidul, obtained and identified by

Cite this article: Sari SR, Elya B, Katrin. Determination of Specific and Non-Specific Parameters of Simplicia and Ethanolic 70\% Extract of Gadung Tubers (Dioscorea hispida). Pharmacog J. 2019;11(4):759-63. 
microscopic and morphology characteristics at the Center for Plant Conservation-Bogor Botanical Garden.

\section{Extraction}

Dried powdered gadung tubers $(500 \mathrm{~g})$ were macerated by using ethanol $70 \%(1: 10)$ and then evaporated.

\section{Standardization}

Standardization was done on simplicia and extract. Parameter test for simplicia consists of two parameters that are the specific parameter and non-specific parameter. The specific parameter consists of macroscopic, organoleptic, microscopic, water soluble extract, ethanol soluble extract, thin layer chromatography, phytochemical screening, and chemical content. The non-specific parameter consists of loss on drying, total ash and total acid insoluble ash.

Parameter test for extract consists of two parameters that are the specific parameter and the non-specific parameter. The specific parameter consists of organoleptic, phytochemical screening and chemical content. The non-specific parameter consists of total water content, total ash and total acid insoluble ash.

\section{RESULTS}

The results showed that macroscopic of D. hispida tubers from the three regions have similarities in the form thin slices of the tuber with uneven edges, speckled surface, tuber $1-2 \mathrm{~cm}$ length, tuber $2-3 \mathrm{~cm}$ width and brown colored. Organoleptic of $D$. hispida tubers powder from the three regions have similarities in the form of dry powder, brown colored, odorless and tasteless. Microscopic of D. hispida tubers powder from the three regions have similarities in fragments consists of parenchymal fragments, cork tissue with rectangular or polygonal cells, concentric round irregularly shaped single starch grains, needle-shaped calcium oxalate crystals, vascular file fragments with thickened nets (Figures 1 and 2).

D. hispida tubers from the three regions have similarities contains alkaloids, tannins, saponins, flavonoids, terpenoids and glycosides. The yield from the three regions was $16.10-16.12 \%$. Organoleptic of $D$. hispida tuber extract from the three regions have similarities viscous extract form, blackish brown colored, odorless, bitter. D. hispida tubers extract from the three regions have similarities contains alkaloids, tannins, saponins, flavonoids, terpenoids and glycosides (Tables 1,2 and 3).

\section{DISCUSSION}

Preparation of $D$. hispida tubers simplicia was obtained from Bogor, Sragen and Gunung Kidul. The material is selected based on the height of the regions. Samples are wet sorting to clean from dirt or other foreign material from simplicia. Then washed with water to remove soil and other impurities. Samples are carried out to accelerate the drying process and dried in a drying cabinet to get simplicia that not easily damaged so that it can be stored for a longer time. Simplisia which has been dried is sorting to separate foreign objects such as unwanted parts of plants and impurities that still exist in dry simplicia. ${ }^{9}$

Parameter test for simplicia of $D$. hispida tuber consists of two parameters that are specific parameters and non-specific parameters. The specific parameters related to the original content of the original plant compounds and the compounds of change from the original plant which are responsible for the pharmacological activity. ${ }^{8}$ The nonspecific parameters related to environmental factors, contamination

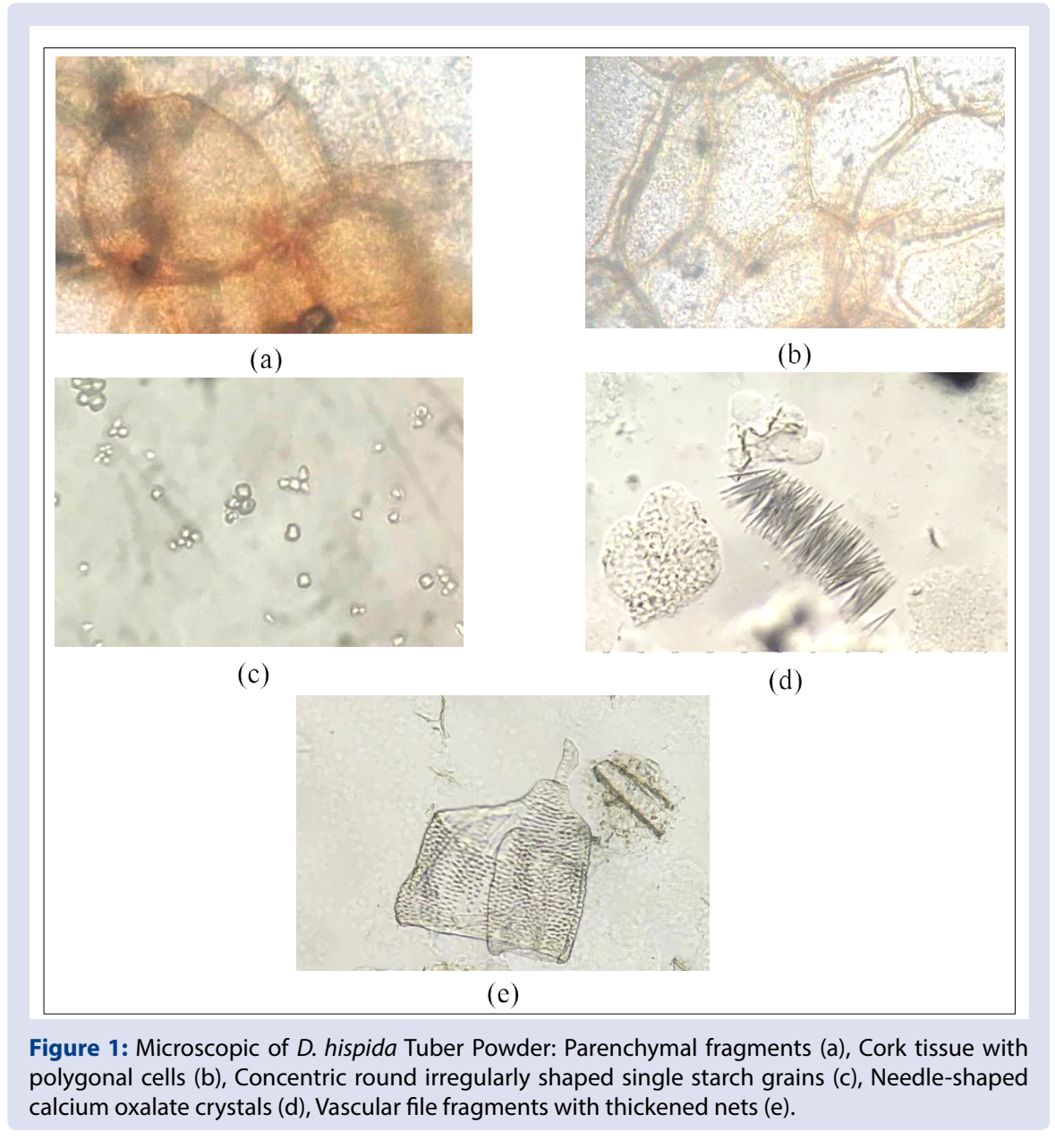




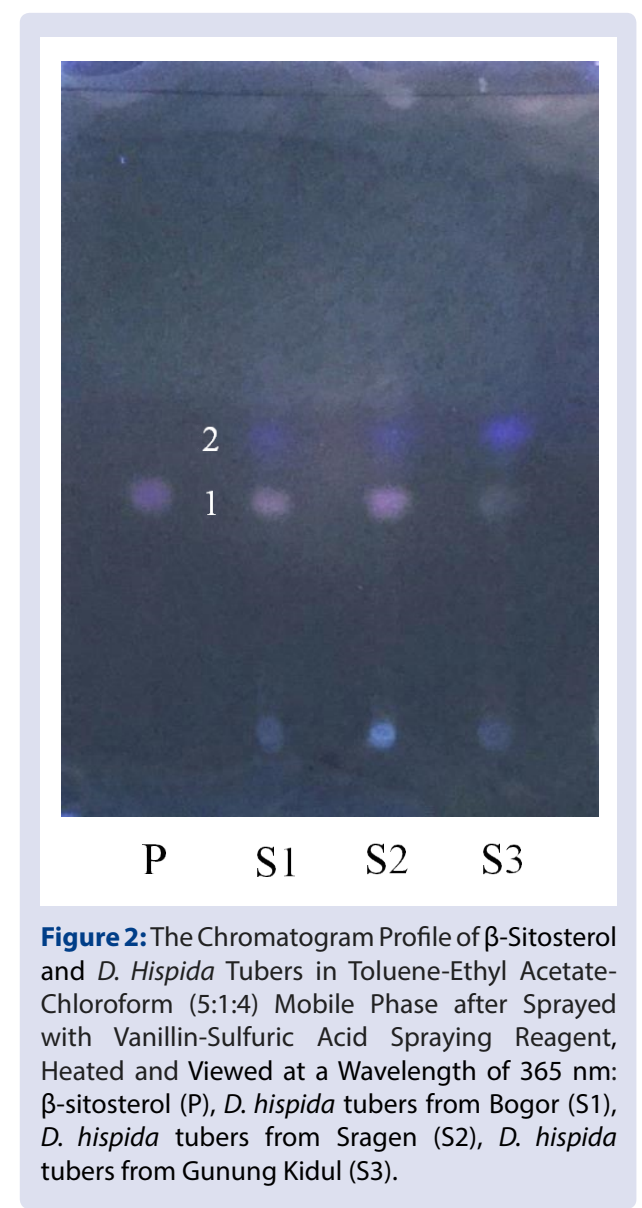

Table 1: Parameter test results for $D$. hispida tubers.

\begin{tabular}{|c|c|c|c|c|}
\hline Test & Bogor & Sragen & Gunung kidul & Range of values \\
\hline \multicolumn{5}{|l|}{ 1. The specific parameter } \\
\hline - Water soluble extract & $11.25 \%$ & $16.20 \%$ & $14.94 \%$ & $11.25-16.20 \%$ \\
\hline - Ethanol soluble extract & $6.42 \%$ & $9.39 \%$ & $7.69 \%$ & $6.42-9.39 \%$ \\
\hline - Total phenolic content & 2.39 mgGAE/g simplicia & $2.15 \mathrm{mgGAE} / \mathrm{g}$ simplicia & $2.50 \mathrm{mgGAE} / \mathrm{g}$ simplicia & 2.15-2.50 mgGAE/g simplicia \\
\hline \multicolumn{5}{|c|}{ 2. The non-specific parameter } \\
\hline - Loss on drying & $12.40 \%$ & $11.51 \%$ & $10.53 \%$ & $10.53-12.40 \%$ \\
\hline - Total ash & $5.94 \%$ & $5.87 \%$ & $5.81 \%$ & $5.81-5.94 \%$ \\
\hline - Total ash insoluble ash & $0.22 \%$ & $0.21 \%$ & $0.20 \%$ & $0.20-0.22 \%$ \\
\hline
\end{tabular}

Table 2: The chromatographic results profile of $\beta$-Sitosterol and $D$. Hispida tubers in Toluene-Ethyl Acetate-Chloroform (5:1:4) mobile phase after sprayed with vanillin-sulfuric acid spraying reagent, heated and viewed at a wavelength of $365 \mathbf{n m}$.

\begin{tabular}{ccc}
\hline Spot number & Rf value of UV $366 \mathrm{~nm}$ & Spot color \\
\hline$\beta$-sitosterol & 0.38 & Purple \\
1 & 0.38 & Purple \\
2 & 0.48 & Blue \\
\hline
\end{tabular}

Table 3: Parameter test results for $D$. hispida tubers extract.

\begin{tabular}{|c|c|c|c|c|}
\hline Test & Bogor & Sragen & Gunung kidul & Range of values \\
\hline \multicolumn{5}{|l|}{ 1. The specific parameter } \\
\hline - Total phenolic content & $10.73 \mathrm{mgGAE} / \mathrm{g}$ extract & $10.30 \mathrm{mgGAE} / \mathrm{g}$ extract & $11.72 \mathrm{mgGAE} / \mathrm{g}$ extract & $10.30-11.72 \mathrm{mgGAE} / \mathrm{g}$ extract \\
\hline \multicolumn{5}{|c|}{ 2. The non-specific parameter } \\
\hline - Total water content & $10.47 \%$ & $10.46 \%$ & $10.27 \%$ & $10.27-10.47 \%$ \\
\hline - Total ash & $2.91 \%$ & $2.93 \%$ & $2.84 \%$ & $2.84-2.93 \%$ \\
\hline - Total acid insoluble ash & $0.14 \%$ & $0.15 \%$ & $0.19 \%$ & $0.14-0.19 \%$ \\
\hline
\end{tabular}


compounds such as pollutants or process additives and compounds result from the interaction of contamination with original compounds or compounds of change that can affect safety and stability. ${ }^{8,10}$

The specific parameters of the simplicia consist of macroscopic simplicia tests to find the morphological specificity, size and color of the simplicia. The organoleptic powder is used for initial recognition as simple and objective as possible. Microscopic is to become a characteristic element of tissue anatomy so that it can be known the type of simplicia based on specific identification fragments. The water soluble extract is to obtain the number of compounds that can be absorbed by water solvents, higher yields of the water soluble extract than the ethanol soluble extracts indicate that simplicia contains more polar compounds so that it is more soluble in water. ${ }^{8,11}$ The ethanol soluble extract is to obtain the number of compounds that can be absorbed with ethanol solvents. Phytochemical screening in simplicia of $D$. hispida is the same as extract. Thin layer chromatogram profile is to provide an initial description of the composition of the chemical content. ${ }^{8}$ Determination of simplicia and extract by using total phenolic content because the plants have high phenol content. ${ }^{3}$

The non-specific parameters of the simplicia consist of the total loss on drying that is to provide maximum limits about the amount of compound lost during the drying process, the compounds can be lost after heating at $105^{\circ} \mathrm{C}$ including water and compounds volatile for example essential oils. ${ }^{8,12}$ The total ash content is to provide internal and external mineral content in simplicia, if the value of the total ash content is high that means there is any mineral content in the ingredients. ${ }^{8,13}$ The total acid insoluble ash content is to illustrate the amount of mineral content that is not soluble in acid, a high value of the total acid insoluble ash content indicate that is compounds has silicate content from soil or sand, silver metal elements, lead and mercury. ${ }^{8,14}$

The maceration method was chosen in this study because of the easiest and simplest method. ${ }^{15}$ Maceration by using $70 \%$ ethanol as a solvent to attract all chemical components, because ethanol is universal solvents that can attract soluble compounds in non-polar to polar solvents. ${ }^{16}$

Parameter tests for the extract of $D$. hispida tuber consist of two parameters that are specific parameters and non-specific parameters. The specific parameters of the extract consist of organoleptic extract test for initial recognition in a simple and objective manner. Phytochemical screening in extracts is more visible from simplicia. ${ }^{8}$

The non-specific parameters of the extract consist of water content that is to provide a minimum range amount of water content in the extract, high yields can occur due to the water coming from the humidity level of the environment during in the storage and absorption of moisture from the air during in the storage before inspection. ${ }^{8}$ The water content that is too high can cause the growth of microbes which will reduce the stability of the extract. ${ }^{17}$ The total ash content is to illustrate internal and external mineral content in simplicia, if the value of the total ash content is high that means there is any mineral content in the ingredients. ${ }^{8,13}$ The total acid insoluble ash content is to illustrate the amount of mineral content that is not soluble in acid, a high value of the total acid insoluble ash content indicate that is compounds has silicate content from soil or sand, silver metal elements, lead and mercury. ${ }^{8,14}$

\section{CONCLUSION}

The results showed that the specific parameters of $D$. hispida tubers were thin slices of tuber with uneven edges, speckled surface, tuber 1-2 $\mathrm{cm}$ length, tuber $2-3 \mathrm{~cm}$ width and brown colored; the results of simplicia were dry powder, brown colored, odorless and tasteless; the identification fragments consists of parenchymal fragments, cork tissue with rectangular or polygonal cells, concentric round irregularly shaped single starch grains, needle-shaped calcium oxalate crystals, vascular file fragments with thickened nets; the total water soluble not less than $11.25 \%$; the total ethanol soluble not less than $6.42 \%$; the chromatogram profile by using thin layer chromatography in tolueneethyl acetate-chloroform (5:1:4) mobile phase with $\beta$-sitosterol as standard, it was sprayed with vanillin-sulfuric acid spraying reagent; phytochemical screening gave positive results on alkaloids, tannins, saponins, flavonoids, terpenoids and glycosides; the total phenolic content not less than 2.15 expressed in $\mathrm{mgGAE} / \mathrm{g}$ simplicia. The nonspecific parameters of $D$. hispida tubers, the total loss on drying not more than $12.40 \%$; the total ash content not more than $5.94 \%$; the total acid insoluble ash content not more than $0.22 \%$. The yield of extract not less than $16.10 \%$.

The specific parameters of $D$. hispida tubers extract, the resulting extract was in viscous extract form, blackish brown colored, odorless, bitter; phytochemical screening gave positive results on alkaloids, tannins, saponins, flavonoids, terpenoids and glycosides; the total phenolic content not less than 10.30 expressed in mgGAE/g extract. The nonspecific parameters of $D$. hispida tubers extract, the total water content not more than $10.47 \%$; the total ash content not more than $2.93 \%$; the total acid insoluble ash content not more than $0.19 \%$.

\section{ACKNOWLEDGMENTS}

The authors are thankful to Universitas Indonesia who had given financial support for this research.

\section{CONFLICTS OF INTEREST}

The authors report no conflicts of interest.

\section{ABBREVIATIONS}

D. hispida: Dioscorea hispida; GAE: Gallic Acid Equivalent.

\section{REFERENCES}

1. Nashriyah M, Salamah T, Nuratiqah M, Indah O, Azhar A, Munirah S, et al. Ethnobotany and distribution of Dioscorea hispida Dennst. (Dioscoreaceae) in Besut, Marang and Setiu Districts of Terengganu, Peninsular Malaysia. International Journal of Agricultural and Biosystems Engineering. 2012;6(12).

2. Badan Penelitian dan Pengembangan Kesehatan. Inventaris Tanaman Obat Indonesia (I). Jakarta: Departemen Kesehatan Republik Indonesia; 1991.

3. Punith KTG, Panduranga MG, Suresh A, Suresh V, Senthil K.N, Raviashankar HG. Evaluation of antitumour activity and antioxidant status in Dioscorea hispida, Dennst. Leaves on Ehrlich Ascites Carcinoma in Swiss Albino Mice. International Journal of Drug Development and Research. 2011;3(2):203-10.

4. Szakiel A, Grabarczyk M, Paczkowski C, Mieczkowski A. Comparison of the profiles of non-glycosylated triterpenoids from leaves of plants of selected species of genus dioscorea. Phytochemistry Letters. 2017;20:350-5.

5. Lokman EF, Muhammad H, Awang N, Omar MH, Mansor F and Saparuddin F. Gene expression profiling associated with hepatoxicity in pregnant rats treated with Ubi Gadong (Dioscorea hispida) extract. International Journal of Biomedical Science. 2017;13(1):26-34

6. LuY, Chia C, LiuY, HouW. Biological activities and applications of dioscorins, the major tuber storage proteins of Yam. Journal of Traditional and Complementary Medicine. 2012:2(1):41-6.

7. Panduranga M, Punith K, Suresh A, Raviashankar H, Chandrasekhar K, Lokesh S. Evaluation of ethanolic leaf extract of Dioscorea hispida Dennst. for antiinflammatory and analgesic activities. Journal of Pharmaceutical and Medicinal Sciences. 2011:2(1):32-9.

8. Departemen Kesehatan Republik Indonesia. Parameter Standar Umum Ekstrak Tumbuhan Obat. Jakarta: Departemen Kesehatan Republik Indonesia; 2000.

9. Prasetyo, Inoriah E. Pengelolaan budidaya tanaman obat-obatan (Bahan Simplisia). Bengkulu: Badan Penerbitan Fakultas Pertanian UNIB; 2013.

10. Zainab, Gunanti F, Witasari H, Edityaningrum C, Mustofa, Murrukmihadi M Penetapan parameter standardisasi non spesifik ekstrak etanol daun belimbing wuluh (Averrhoa bilimbi L.). Prosiding Rakernas dan PIT IAI. 2016. 
11. Muchtaridi, Rubiyanti R, Nuruljanah $H$, Laila M, Asih N, MW M, et al. Determination of parameters standardization crude drug and extract arabica coffee beans (Coffea arabica L.). International Journal of Scientific and Technology Research. 2017;6(2)

12. Yunarto N, Sulistyaningrum N. Quantitative analysis of bioactive compounds in extract and fraction of star fruit (Averrhoa carambola L.) leaves using high performance liquid chromatography. Jurnal Kefarmasian Indonesia. 2017;7:2633.

13. UtamiYP, Umar AH, Syahruni R, Kadullah I. Standardisasi simplisia dan ekstrak etanol daun leilem (Clerodendrum minahassae Teisjm. and Binn.). Journal of Pharmaceutical and Medicinal Sciences. 2017;2(1):32-9.
14. Guntarti A, Sholehah K, Irna N, Fistianingrum W. Penentuan parameter non spesifik ekstrak etanol kulit buah manggis (Garcinia mangostana) pada variasi asal daerah. Farmasains. 2015;2(5).

15. Azwanida NN. A review on the extraction methods use in medicinal plants, principle, strength and limitation. Medicinal and Aromatic Plants. 2015;4(3):196.

16. Artini P, Astuti KW, Warditiani NK. Skrining fitokimia ekstrak etanol $70 \%$ rimpang bangle (Zingiber purpureum Roxb.). Jurnal Farmasi Udayana. 2013.

17. Saifudin A, Rahayu V, Teruna HY. Standardisasi Bahan Obat Alam. Yogyakarta: Graha IImu; 2011.

\section{SUMMARY}

D. hispida tubers and extract conform the specific and non-specific parameters.

Cite this article: Sari SR, Elya B, Katrin. Determination of Specific and Non-Specific Parameters of Simplicia and Ethanolic 70\% Extract of Gadung Tubers (Dioscorea hispida). Pharmacog J. 2019;11(4):759-63. 